\title{
RFID Teknolojisinin Kullanıcılar Tarafından Kabulünün Carfid Modeli İle İncelenmesi: Üniversite Öğrencilerine Yönelik Bir Araştırma
}

\author{
DOI: 10.26466/opus.927695
}

\author{
$*$ \\ Ahmet İker Akbaba* - Muhammet Mutlu ** \\ * Dr. Öğr. Üyesi, Erzurum Teknik Üniversitesi, İiBF, Erzurum/Türkiye \\ E-Posta: aakbaba@erzurum.edu.tr \\ ORCID: $\underline{0000-0003-3256-441 X}$ \\ ** Araş. Gör., Erzurum Teknik Üniversitesi, İiBF, Erzurum/Türkiye \\ E-Posta: muhammet.mutlu@erzurum.edu.tr \\ ORCID: $\underline{0000-0003-3138-2139}$
}

\section{Öz}

RFID teknolojisi sayısız uygulama alanında kullanılabilen ve benimsenmesinde çok farklı avantajlar sunan bir teknoloji olmasına rağmen barkod teknolojisinin gerisinde kalmış ve kullanıcılar tarafından kabulü beklentileri karşılamamıştır. Bu çalışmadaki amaç, araştırma modelinde yer alan değişkenlerin öğrencilerin RFID teknolojisi kullanım niyetleri üzerinde etkili olup olmadığın ve RFID teknolojisi kullanım niyetinin de cinsiyete, fakülteye ve öğrenim görülen sınıfa göre farklılık gösterip göstermediğini ortaya çıkarmaktır. Araştırmaya veri elde etmek için Erzurum Teknik Üniversitesi'nde dört farkl fakültede öğrenim gören öğrencilere online anket uygulanmıştır. Verilerin analizi için, frekans, aritmetik ortalama ve standart sapma, açıklayıcı faktör analizi, güvenilirlik analizi, çoklu regresyon analizi, $t$-testi ve tek yön Anova analizi yapılmıştır. Analizlerde, SPSS 22.0 paket istatistik programı kullanılmıştır. Yapılan analizlerde, kullanım kolaylığı ve kullanışlılık, yasal düzenlemeler, kültür ve arkadaş çevresinin etkisi, kişisel bilgilere erişimi kontrol etme ve paylaşma isteği değiş̧kenlerinin RFID teknolojisi kullanma niyeti üzerinde anlamlı bir etkiye sahip olduğu ve RFID teknolojisi kullanma niyetinin fakültelere göre farklllık gösterdiği sonucu elde edilmiştir.

Anahtar Kelimeler: Rfid Teknolojisi, Carfid Modeli, Öğrenci. 


\title{
Review of the User's Acceptance of RFID Technology with the Carfid Model: A Research for University Students
}

\begin{abstract}
Although RFID technology can be used in many applications and offers many different advantages in its adoption, it has remained behind barcode technology and did not meet user acceptance expectations. The purpose of this study is to reveal whether the variables in the research model have an effect on the students' intention to use RFID technology and whether the intention to use RFID technology differs according to gender, faculty, and the class of education. In the study, for data obtaining an online survey was applied to students studying in four different faculties in Erzurum Technical University. For the data analysis, frequency, arithmetic mean and standard deviation, explanatory factor analysis, reliability analysis, multiple regression analysis $t$-test and one-way Anova analysis were performed. SPSS 22.0 package statistics program was used in the analyzes. With the conducted analysis, it was obtained that the variables of ease of use and usefulness, regulations, the influence of culture and friends, the controlling of personal information access, and willingness of personal information share have a significant effect on the intention to use RFID technology, and the intention to use RFID technology differs according to the faculties.
\end{abstract}

Keywords: Rfid Technology, Carfid Model, Student. 


\section{Giriş}

RFID teknolojisinin veri depolama ve varlık kontrolü için geleceğin teknolojisi olduğuna inanılmaktadır. RFID teknolojisi, insan müdahalesi olmadan veri depolanması ve transferi için radyo dalgalarını kullanan ve hızlı şekilde gelişen bir teknolojidir (Yao, Chu ve $\mathrm{Li}, 2010$, s.128). RFID teknolojisinin hızlı gelişimi, hayatı kolaylaştıran sistemlere sağladığı imkânlar ve maliyeti gibi etkenler RFID uygulamalarının sayısını artırmıştır (Maraşlı ve Çıbuk, 2015, s.266). RFID teknolojisinin kullanılmasıyla, iş yüklerinde önemli ölçüde azalış, şirket verimliliğinde artış, stok kontrol ve provizyon maliyetlerinde azalış, daha az personel bulundurma, bakım maliyetinin düşük olması veya hiç olmaması, farklı ve zor koşullarda çalışabilmesi ve uzun süre etkin bir şekilde kullanılabilmesi, etiket okuma kapasitesinin çok hızlı olması, sensor gibi, diğer teknolojilerle entegre olabilmesi, büyük miktarda veri depolayabilmesi, nesneleri bireysel algılayabilmesi, giriş ve çıkışlarda hızlı kontrol sağlaması gibi birçok fayda elde edilebilmektedir ( Roberts, 2006, s.21, Pala ve İnanç, 2007, s.1, Ahuja ve Potti 2010, s.183, Kaur, Sandhu, Mohan and Sandhu, 2011, s.154). RFID teknolojisi yukarıda sağlanan faydalarının yanında göz önüne bulundurulması gereken birtakım dezavantajlara da sahiptir. RFID teknoloji kullanımıyla depolanan verilere yönelik gizlilik tehditleri ortaya çıkarak güvenlik ve mahremiyet sorunların doğurabilmektedir (Sarma, Weis and Engels, 2002, s.465). RFID verilerine erişebilmenin kolay olmasından dolayı bilgilerin klonlanabilmesinin önüne geçilmesi zorlaşmıştır (Ahuja and Potti, 2010, s.185). Verilerin üçüncü taraflarla paylaşılması, bireylerin takip edilmesine neden olabilmektedir (Saatçığlu, 2006, s.27).

Barkod teknolojisine de benzetilen RFID teknolojisi, kablosuz bir teknoloji olması ve bu teknoloji de yer alan sistemlerin birbirine temas etmeden okuma ve yazma imkânı sunması barkod teknolojilerinin de kullanılmadığı zorlu ortamlarda bile kolaylıklar sağlamaktadır (Bazaatı, 2012, s.7). Barkod teknolojisinden daha etkili ve gözle görülebilen avantajlar sunmasına rağmen, barkod gibi diğer -teknolojilerinin gerisinde kalmış gelişimi ve dağılımı beklentileri karşılamamıştır (Yao ve diğ., 2010, s.128). Kullanıcılar açısından bu teknoloji için güvenlik, kişisel bilgilere gelebilecek olası saldırı endişesi ve kişisel verilere yönelik tehditler gündeme getirilmekte ve bu so- 
runların kullanıcılar tarafından RFID teknolojisi kabulü için ele alınması gerekmektedir (Hossain ve Prybutok, 2008, s.316). Bu sorunlardan yola çıkılarak bu çalışmada RFID teknolojisi kabulü için oluşturulan model ve bu modeldeki değişkenlerde, Hossain ve Prybutok (2008) tarafından RFID teknolojisi kabulü üzerine yapılan çalışma referans olarak alınmıştır.

Bu çalışmada, RFID teknolojisi tüketici kabul modelini (CARFID) dikkate alarak modelde yer alan kullanım kolaylığı ve kullanışlılık, yasal düzenlemeler, kültür ve arkadaş çevresinin etkisi, kişisel bilgilere erişimi kontrol etme ve paylaşma isteği değişkenlerinin öğrencilerin RFID teknolojisi kullanım niyetleri üzerinde etkili olup olmadıklarını ve RFID teknolojisi kullanım niyetinin, cinsiyete, fakülteye ve öğrenim görülen sinıfa göre farklılık gösterip göstermediğini ortaya çıkarmak amaçlanmaktadır.

Araştırma için Erzurum Teknik Üniversitesi IÏBF, Edebiyat, Mühendislik.Mimarlık ve Fen Fakültelerinde öğrenimlerini sürdüren 343 öğrenciye online anket uygulanmıştır. Hatalı ve eksik anketler çıkarıldıktan sonra kalan 330 anket dikkate alınmıştır. Analizler için SPSS Statistic 22.0 paket programı ile frekans, aritmetik ortalama ve standart sapma, açıklayıcı faktör analizi, güvenilirlik analizi, çoklu regresyon analizi t-testi ve tek yön Anova analizi yapılmıştır.

\section{Kavramsal Çerçeve}

Rfid Teknolojisi: RFID teknolojisinin gelişimi 1880 'li yıllara kadar uzanmaktadır. 1880'lerin başında elektromanyetik dalga teorisinde ilk gelişmeler elde edilmiş, 1846 ' da ışık ve radyo dalgalarının elektromanyetik enerji oluşturduğunu ortaya konmuştur. 1887'de radyo sinyallerinin gönderimi ve alımı başarılmıştır (Bazaatı, 2012, s.11-12). 1906'da Ernst F.W. Alexanderson, ilk radyo dalgasının nasıl üretilebileceğini ve radyo sinyallerinin nasıl iletilebileceğini göstermiştir (Domdouzis, Kumar ve Anumba, 2007, s.351). II. Dünya Savaşı sırasında İngilizler, dost uçakları ile düşmanın uçaklarını ayırmak için Identify-Friend veya Foe (IFF) isimli aktarıcıyı geliştirmiş, bu aktarıcı müttefikler tarafından kullanılmıştır (Chawla and Ha, D. S. 2007, s.11, Domdouzis, Kumar ve Anumba, 2007, s.35, Jia, Feng, Fanm and Lei, 2012, s.1282). Stockman tarafından oluşturulan "Communication By Means of Reflected Power" RFID teknolojisinin temelini oluşturan ilk çalışmalar arasında yerini almıştır (Roberts, 2006, s.18, Domdouzis, Kumar ve Anumba, 2007, 
s.351, Çıbuk ve Maraşli, 2015, s.252, Bayrak, 2017, s.55). RFID teknolojisinin ilk ticari uygulaması, 1960'ların sonlarında Sensormatic ve Checkpoint gibi şirketler tarafindan geliştirilmiştir (Chawla and Ha, 2007, s.11). Bu ticari sistemler, hırsızlık önleme cihazı olarak kullanılan elektronik ürün izleme (EAS) ekipmanyla piyasaya sürülmüştür (Roberts, 2006, s.19, Domdouzis, Kumar ve Anumba, 2007, s.351). Giyim mağazalarında ve kütüphanelerde hırsızlığ önlemek amaciyla kullanılan EAS sistemleri bugünkü RFID uygulamalarının temelini oluşturmakladır (Çıbuk ve Maraşlı, 2015, s.251). 1970'ler boyunca, Los Alamos Bilimsel Laboratuvarı ve Northwestern Üniversitesi gibi araştırma kuruluşları RFID araştırmalarına dâhil olmuştur (Domdouzis, Kumar ve Anumba, 2007, s.351). Raytheon ve RCA gibi büyük şirketler elektronik kimlik sistemleri geliştirmiştir (Domdouzis, Kumar ve Anumba, 2007, s.351).

1980'li yıllarda RFID uygulamaları, birçok alana yayılmaya başlamıştır (Roberts, 2006, s.19, Çıbuk ve Maraşlı, 2015, s.251). Hayvan takip sistemleri yaygınlaşmış ve ABD, İtalya, Fransa, İspanya, Portekiz ve Norveç'teki ücretli yollar RFID ile donatılmıştır (Roberts, 2006, s.19, Çıbuk ve Maraşlı, 2015, s.251).

1990'lardan sonra RFID'in ticari olarak kullanımındaki artışı, standartlara olan ihtiyacı doğurarak birçok standardizasyon faaliyetlerinin yürütülmesine neden olmuştur. Bu faaliyetlerin çoğu Uluslararası Standartlar Organizasyonu (ISO) ve Uluslararası Elektroteknik Komisyonu (IEC) tarafından gerçekleştirilmiştir (Chawla and Ha, D. S. 2007, s.11).

2000'li yıllarda küçük boyutlarda RFID'ler üretilerek birçok sisteme dâhil edilebilmiştir (Çıbuk ve Maraşlı, 2015, s.251). 2000'li yıllarda, Wal-Mart ve Metro gibi büyük perakende zincirleri ile Department of Defense gibi resmi kurumlar, tedarikçilerinin RFID sistemlerini kullanmaları için yaptırım kararları almışlardır. MIT Üniversitesi Auto-ID Laboratuvarı ile Elektronik Ürün Kodu (EPC) standartlarının gelişmesi için çalışmalar yapmıştır. EPCGlobal organizasyonu standartlar için kurulmuş ve RFID standartlarının geliştirilmesi için faaliyet göstermeye başlamıştır (Bazaatı, 2012, s.13).

RFID teknolojisi, etiketlerin uzaktan okunmasını sağlayan kablosuz iletişim teknolojisidir (Nath, Reynolds and Want, 2006, s.22, Pala ve İnanç, 2007, s.1). RFID nesneleri otomatik olarak tanımlamak ve izlemek için radyo dalgalarını kullanmaktadır (Chen, Papazafeiropoulou, WU ve Huang, 2011, s.12, Jones, Clarke-Hill, Hillier, ve Comfort, 2005, s.396, Bottani ve Rizzi, 2008, s.548). Bir 
nesne veya kişiye ait tanıma bilgisini kablosuz bir şekilde radyo dalgaları ile iletmek için kullanılan sistemleri tanımlamak amacıyla ifade edilen genel bir terimdir (Bayrak, 2017, s.54). RFID (Radio Frequency Identification)- Radyo frekanslı tanımlama, insan müdahalesi olmaksızın nesneleri tanımlayan ve bu nesneleri takip eden, bilgilerin işlenmesini sağlayan bilgi ve iletişim teknolojilerini kapsayan genel bir tanımlamadır (Erinç, 2014, s.18). Bu teknoloji, makinelere veya bilgisayarlara nesneleri tanımlamada, meta verileri kaydetmede veya radyo dalgaları aracılığıyla tek tek hedefleri kontrol etmede yardımci olarak (Jia, Feng, Fanm and Lei, 2012, s.1282), kablosuz veri aktarımını mümkün kılan en temel teknolojilerden biridir. Uzun zamandır bilinmesine rağmen pahalı olmasından ve standartlara sahip olmamasından dolayı yaygın olarak kullanılması uzun zaman almıştır (Pala ve İnanç, 2007, s.1). Barkod teknolojisine benzeyen RFID teknolojisi, bazı kitleler tarafindan en yaygın kullanılan bilgisayar teknolojilerinden birisi olarak görülmektedir (Roberts, 2006, s.18). Fakat RFID teknolojisi kablosuz bir teknoloji olduğu için bu teknolojide sistemler birbirine temas etmeden hatta görünür dahi olmadan okuma ve tanıma imkânı sunmaktadır. Bu özelliğinden dolayı, barkod gibi geleneksel teknolojilerin kullanılamadığı zorlu ortamlarda büyük kolaylıklar sağlamaktadır (Bazaatı, 2012, s.7)

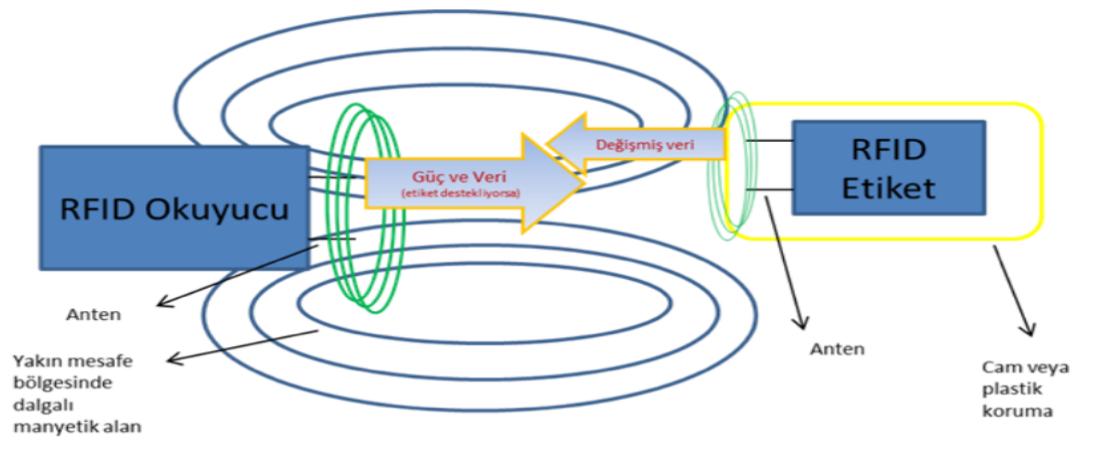

Şekil 1. RFID Teknolojisinin Temel Çalışma Prensibi (Maraşlı ve Çıbuk, 2015, s.250)

RFID sistemleri, etiket (tag, transponder), okuyucu, okuyucuya bağlı antenler, bilgisayar ve sistem yazılımlarından oluşmaktadır (Bazaatı, 2012: 7). $\mathrm{Bu}$ teknolojide etikete, nesneleri tanımlamak için bir seri numarası atanır ve 
bu etiket fiyat, saat, tarih bilgileri de barındırabilir (Zhangm, Ouyang, ve He, 2008, s.107). Etiketler, sarmal bir anten ve bir mikroçipten oluşarak aktif veya pasif olabilirler (Jia, Feng, Fanm ve Lei, 2012, s.1283). Antenler, etiket ve alıc1verici arasındaki iletişimi sağlar (Domdouzis, Kumar and Anumba, 2007, s.350). Antenler sayesinde, okuyucu alanina giren etiket, okuyucuya kendi bilgilerini sinyaller ile gönderir. Okuyucudan gelen elektromanyetik dalgalar etiketin antenine ulaşarak, etikette bulunan mikroçipteki devreleri harekete geçirip, mikroçip dalgalarını modüle ederek anten ile okuyucuya geri gönderir (Çıbuk ve Maraşlı, 2015, s.252)

RFID teknolojisinin hızlı gelişimi, hayatı kolaylaştıran sistemlere sağladığ1 imkânlar ve maliyeti gibi etkenler, RFID uygulamalarının sayısını artırmıştır (Maraşlı ve Çıbuk, 2015, s.266). RFID teknolojisi, perakende stok yönetimi, kütüphane kitap takibi, hırsızlık önleme (Roberts, 2006, s.18), gişelerde ücretli araç geçişi, polis departmanları tarafından çalınan arabaları ve diğer araçları takip etme, hayvan hastalıklarını takip etme ve kontrol etme, tutukluları takip etme, hasta takibi ve havayolu endüstrisinde yolcu bagajları takibi gibi birçok alanda kullanılabilmektedir (Ahuja and Potti, 2010, s.184)

RFID teknolojisinin kullanılmasıyla, iş yüklerinde önemli ölçüde azalış, şirket verimliliğinde artış, stok kontrol ve provizyon maliyetlerinde azalış, daha az personel bulundurma, bakım maliyetinin düşük olması veya hiç olmaması, farklı ve zor koşullarda çalışabilmesi ve uzun süre etkin bir şekilde kullanılabilmesi, etiket okuma kapasitesinin çok hızlı olması, sensor gibi, diğer teknolojilerle entegre olabilmesi, büyük miktarda veri depolayabilmesi, nesneleri bireysel algılayabilmesi, giriş ve çıkışarda hızlı kontrol sağlaması gibi birçok fayda elde edilebilmektedir (Roberts, 2006, s.21, Pala ve İnanç, 2007, s.1, Ahuja ve Potti 2010, s.183, Kaur, Sandhu, Mohan and Sandhu, 2011, s.154).

RFID teknolojisi, yukarıda sağlanan faydaların yanında göz önüne bulundurulması gereken birtakım dezavantajlara da sahiptir. RFID teknoloji kullanımıyla depolanan verilere yönelik gizlilik tehditleri ortaya çıarak güvenlik ve mahremiyet sorunların doğurabilmektedir (Sarma, Weis and Engels, 2002, s.465). RFID verilerine erişebilmenin kolay olmasından dolayı bilgilerin klonlanabilmesinin önüne geçilmesi zorlaşmıştır (Ahuja and Potti, 2010, s.185). Verilerin üçüncü taraflarla paylaşılması, bireylerin takip edilmesine neden olabilmektedir (Saatçıŏlu, 2006, s.27) 


\section{Literatür Taraması}

Hossain ve Prybutok (2008) RFID teknolojisi kapsaminda teknoloji kabul modelini (TKM) içeren bir teorik model geliştirmek, test etmek ve tüketicinin RFID teknolojisinin kabulünü etkileyen faktörleri araştırmayı amaçladıkları çalışmada, algılanan kolaylık, algılanan kültür ve algılanan güvenliğin tüketicilerin RFID teknolojisini kabul etme istekliliği üzerinde önemli bir etkisi olduğu fakat yasal düzenlemelerin RFID kullanma üzerinde etkili olmadığını sonucu elde edilmiştir.

Müller-Seitz vd., (2009) teknoloji kabul modeli (TKM) ele alınarak, bir Alman elektronik perakende zincirinde RFID teknolojisinin müşteri kabulünü incelemeyi amaçlanmadıkları çalışmayla, literatüre üç önemli katkı sağlamışlardır. Birincisi, müşterinin bakış açısı dikkate alınarak RFID teknolojisi seçilmiş ve perakende ortamında müşteri kabulü incelenmiştir. İkincisi, bu çalışma ile RFID teknolojisi ile teknoloji kabul modeli doğrulanmıştır. Üçüncüsü, müşterilerin yeni teknolojilere yönelik genel tutumları ve güvenlik kaygıları birleşerek TKM revize edilmiştir.

Roh ve Kunnathur (2009) yaptığı çalışmada, RFID teknolojisinin benimsenmesinin maliyet tasarrufu, tedarik zincirinin görünürlüğü ve yeni süreç oluşturma olarak üç faydasının olduğu sonucuna varılmıştır. Çalı̧̧mada RFID kabulünün temel boyutları olarak ve ölçek ve kapsam belirlenerek bunların altında dört farklı kabul etme tipi tanımlanmış ve beklenen üç faydanın kabul etme ölçeği ve kapsamı ile nasıl ilişkili olduğunu gösterilmiştir.

Lin ve Ho (2009) çalışmalarında, RFID teknolojisinin kabul edilmesini etkileyen faktörleri ve RFID teknolojisinin kabulü ile lojistik şirketleri için tedarik zinciri performansı arasındaki ilişkiyi incelemişlerdir. Çalışmaya göre hem finansal hem de finansal olmayan tedarik zinciri performanslarının RFID teknolojisini kabullenme istekliliği ile pozitif ilişkili olduğu ve RFID teknolojisinin kabullenilmesi ile tedarik zinciri performansı arasında pozitif bir ilişki olduğu görülmüştür.

Pramatari and Theotokis (2009), teknolojiye dayalı hizmetlere yönelik tüketici tutumlarına odaklanan bir model geliştirerek test ettikleri çalışmalarında, performans ve çalışma beklentisi gibi faktörlerin yanı sıra teknoloji kaygısı ve bilgi gizliliği endişesi gibi bireysel özelliklerin sırasıyla teknoloji tabanlı ve RFID destekli hizmetlere yönelik tüketici tutumunu etkilediği sonucuna ulaşılmıştır. 
Norman, Nasir, Fauzi and Azmi, (2009) Malezya'da RFID teknolojisi ile gıda ürünlerinin Helal durumunun doğrulanmasına yönelik yapmış oldukları çalışmalarında, RFID teknolojisinin kullanılabilirlik, verimlilik, güvenlik, satın alınabilirlik ve karlılık açısından memnuniyetini ölçmek için kullanıcı değerlendirmesi yapılmıştır. Değerlendirmeye dayalı olarak, tüm katılımciların bu yeni teknolojinin performansından memnun kaldıkları sonucuna ulaşılmıştır.

Wang, Wang and Yang (2010) imalat endüstrisinde RFID'in benimsenmesinin belirleyicileri üzerine yapmış oldukları çalışmada, bir firmanın imalat endüstrisinde RFID uygulayıp uygulamadığı, firmanın teknolojik, organizasyonel ve çevresel bağlamlarına bağlı olduğunu, bilgi yoğunluğu, karmaşıklık, uyumluluk, firma boyutu, rekabet baskısı ve ticaret ortağı baskısının RFID benimsemesinin önemli belirleyicileri olduğu ancak göreceli avantaj, üst yönetim desteği ve teknoloji yeterliliğinin RFID'nin benimsenmesinin önemsiz belirleyicileri olduğu sonucuna ulaşılmıştır.

Li, Wang, Zhang and Chu (2010) teknoloji-organizasyon-çevre çerçevesine dayalı olarak, Çin'de RFID'in kabulü üzerindeki teknolojik, organizasyonel ve çevresel faktörlerin etkilerini incelemeyi amaçladıkları çalışmalarında, çevresel ve organizasyonel bağlamın Çinli firmalarda RFID'in kabulü üzerinde önemli bir etkiye sahip olduğu sonucunu elde etmişlerdir.

Cheng (2013) teknoloji kabul modeline dayanarak RFID kapı güvenlik sisteminin kullanımına yönelik tüketici tutumlarını ve tüketici davranış niyetine yönelik yapmış olduğu çalışmasında, sistem kalitesi ve bilgi kalitesinin algılanan kullanışlılık ve algılanan kullanım kolaylığı üzerinde etkiye, algılanan kullanım kolaylığının algılanan kullanışlılık üzerinde etkiye, algılanan kullanışılıı ve algılanan kullanım kolaylığının kullanıma yönelik tutumlar üzerinde etkiye, kullanmaya yönelik tutumların kullanım için davranışsal niyetler üzerinde etkiye, algılanan kullanışlılığın, kullanım davranışsal niyetleri üzerinde etkiye ve algılanan kullanım kolaylığının, algılanan yararlılığın aracı etkisiyle kullanıma yönelik tutum üzerinde etkiye sahip olduğu sonucu elde edilmiştir.

Öztürk ve Hançer, (2015) konaklama endüstrisinde, müşterilerin bireysel farklılıkları ile RFID teknolojisini kullanma niyetleri arasındaki ilişkiyi 
araştırdıkları çalışmalarında, katılımcıların RFID teknolojisini kullanma niyetinde geçmiş deneyimler ve tüm demografik değişkenler açısından önemli farklılıklar olduğunu elde etmişlerdir.

Nysveen and Pedersen (2016) yapmış oldukları çalışmalarında, performans beklentisi, çaba beklentisi ve teknoloji kaygısının RFID özellikli hizmetleri kullanma tutumu üzerinde önemli etkiye, kullanma tutumunun ve kolaylaştırıc koşulların da RFID özellikli hizmetleri kullanma niyeti üzerinde doğrudan etkiye sahip olduğu sonucuna ulaşılmıştır.

Rfid Teknolojisi Tüketici Kabul Modeli (Carfid): Teknoloji Kabul Modeli (TKM) ilk olarak Davis tarafından geliştirilip kullanılmıştır (Lee, 2009, s.1045). Teknoloji Kabul Modelinin (TKM), önemli bir sosyo-psikolojik teori olan Sebepli Hareketler Teorisi (Theory of Reasoned Action - TRA)'nden uyarlanarak yapılan birçok çalışma ile kuvvetli ve tahmin gücü yüksek bir teori olduğu belirlenmiştir (Akbaba, 2018, s.73-74). Teknoloji kabul modeli, kullanıciların teknolojiyi nasıl kabul ettiklerini ve kullandıklarını modelleyen bir bilgi sistemleri teorisi olup bilgi sistemlerinin kullanıcı kabulü üzerinde en fazla etkiye sahip faktörlerinin açıklanması için yaygın olarak kullanılan modellerden biridir. Algılanan kullanışlılık (PU) ve algılanan kullanım kolaylığı (PEU) olmak üzere iki ana faktör içermektedir. (Çelik, Yılmaz ve Pazarlığlu, 2010, s.36) Algılanan kullanışlılık, bireylerin iş performanslarını belli bir teknoloji kullanarak geliştiğine inandıkları ölçü olarak tanımlanmaktadır. Algılanan kullanım kolaylığı bir sistemi kullanmanın kolay ve zahmetsiz olma ölçüsü olarak tanımlanmaktadır (Hossain ve Prybutok, 2008, s.317).

CARFID Modeli, Teknoloji kabul Modelini esas alarak Hossain ve Prybutok (2008) tarafından geliştirilmiştir. Modelde yer alan algılanan kullanışlılık ve algılanan kullanım kolaylığı birleştirilerek algılanan uygunluk olarak değiştirilmiştir. Modele ayrıca, algılanan kişisel gizlilik hakkı, algılanan kültür etkisi, algılanan güvenlik ve algılanan yasal düzenlemeler eklenerek model genişletilmiştir. Modelde yer alan değişkenlere yönelik açıklamalar aşağıda sunulmaktadır.

Kullanıcıların bilgi sistemini kabul etmesinin önemli bir belirleyicisi olan algilanan kullanım kolaylığı (PEU), belirli bir sistemi kullanmak için gerekli çabanın derecesi olarak ifade edilmektedir. Kullanıcının herhangi bir teknolojiyi kullanırken, belli görevleri yaparken ve sorunları çözerken 
kendisine sağlayacağı performans artışı, algilanan kullanım kolaylığı ile ilgilidir. Algılanan kullanışlılık ise kişilerin bir teknolojinin kendi iş performansını artıracağına inandığı derece olarak tanımlanmaktadır (Armağan, Baysal ve Armağan, 2017, s.382). RFID teknolojisinin teslimat zamanlarının önceden belirlenmesi ve teslimat sürelerinin azalması, tekrarlanan iş tekrarlarının azaltılması, firelerin ve hataların azaltılması, müşteri hizmetlerinin geliştirilmesi, müşterilerin satın alma davranışlarının izlenmesi ve hedef müşterilerin belirlenmesinde kolaylık sağlaması gibi birçok alanda kolaylık sağlamaktadır (Saatçığlu, 2006, s.27). Bireyler, eğer bir teknolojinin kullanımını kolay olarak algılarlarsa ve meslekleri için daha iyi ve daha verimli olacağına inanırlarsa, o teknolojiyi kullanmaya yönelik daha istekli olmaktadırlar (Hossain ve Prybutok, 2008, s.318).

Kültür, bir toplum ya da organizasyonda paylaşllan normlar, değer sistemleri, inançlar ve davranışlar olarak tanımlanmaktadır. Bir kültürün teknoloji üzerinde etkisi bir kültürün bireyleri tarafından teknoloji kullanım niyetini artırmaktadır (Hossain ve Prybutok, 2008, s.318). Akran etkisi, teknoloji kabul edilebilirliği üzerinde etkilidir. Gençlerin, akranlarıyla bir araya gelerek, sosyalleşme ve paylaşımda bulunmak istemeleri, teknoloji kabul edilebilirliğinin ve kullanımı için önemli bir etken olarak görülmektedir (Dinç, 2015, s.51-53).

RFID teknolojisi kullanımı ile ilgili olan yönergeler, RFID teknolojisine olan müşteri güvenini artırabilmekte ve RFID için artan kullanıcı güveni, RFID teknolojisinin kabul edilme üzerinde etkili olacaktır (Hossain ve Prybutok, 2008, s.319).

RFID teknolojisinde etiketler kant olmadan okutulduğu için gizlilik ve güvenlik endişeleri ortaya çıarmaktadır. Gizlilik tehditlerinin çoğu etiketlerin, bir kişinin kimliği ile ilişkilendirilmesi sonucu ile ortaya çıabilmektedir (Lee ve Kim, 2006). Teknoloji kullanımında, yüksek gizlilik kaygısı güden ve kişisel bilgilerin paylaşımına yönelik istekli olmayan kullanıcılar, daha düşük gizlilik endişesi olan ve kişisel bilgileri paylaşmaya daha çok istekli olan müşterilere daha az oranla RFID temelli teknolojileri kullanmaya yönelmektedirler (Hossain ve Prybutok, 2008, s.319). 


\section{Araştırma Metodolojisi}

Araştırmanın Amacı: Kişisel bilgilere erişim ve kontrol, kişisel bilgileri paylaşma isteği, yasal düzenlemeler, kültür ve arkadaş çevresinin etkisi, kullanım kolaylığı ve kullanışlılık gibi faktörlerin RFID teknolojisi kullanım niyeti üzerinde etkisinin olup olmadığını ortaya çıkarmaktır.

Araştırmanın Yöntemi: Araştırma, birincil verilere dayalı olarak RFID teknolojisi kullanım niyeti üzerinde etkiye sahip olan faktörleri ölçmek amacıyla 2019 Kasım ayında Erzurum Teknik Üniversitesi'ne bağlı İ̈BF, Edebiyat, Mimarlık- Mühendislik ve Fen fakültelerinin öğrencilerine yüz yüze/online anket uygulanmış 343 kişiden veri toplanmıştır. Hatalı ve eksik anketler çıkarıldıktan sonra kalan 330 anket değerlendirmeye alınmıştır. Araştırma verilerini toplamak amaciyla kullanılan anket formu toplam 32 sorudan oluşmaktadır. Anket soruları oluşturulurken Hossain ve Prybutok'ın (2008) çalışmasından faydalanılmıştır.

Araştırma Modeli: Araştırmanın modelini 5 ana değişken oluşturmaktadır. Araştırmanın modeli oluşturulurken; Hossain ve Prybutok (2008) tarafından geliştirilen CARFID modeli referans olarak alınmıştır.

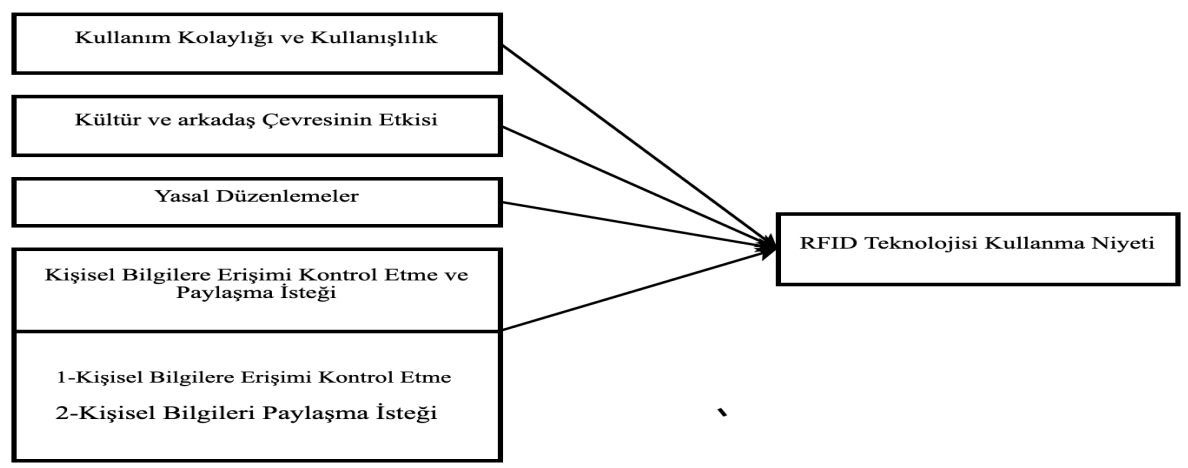

Şekil 2. Araştırma Modeli

Araştırma Hipotezleri: H1: RFID Teknolojisine yönelik kullanım kolaylığı ve kullanışlılığın RFID teknolojisi kullanım niyeti üzerinde anlamlı etkisi vardır. 
H2: RFID Teknolojisine yönelik kültür ve arkadaş çevresinin RFID teknolojisi kullanım niyeti üzerinde anlamlı etkisi vardır.

H3: RFID teknolojisini kullanmaya yönelik kişisel bilgileri koruyan yasal düzenlemelerin RFID teknolojisi kullanım niyeti üzerinde anlamlı etkisi vardir.

H4: Kişisel bilgilere erişimi kontrol etme ve kişisel bilgileri paylaşma isteğinin RFID teknolojisi kullanım niyeti üzerinde anlamlı etkisi vardır.

H4a: Kişisel bilgilere erişimi kontrol etmenin RFID teknolojisi kullanım niyeti üzerinde anlamlı etkisi vardır.

H4b: Kişisel bilgileri paylaşma isteğinin RFID teknolojisi kullanım niyeti üzerinde anlamlı etkisi vardır.

H5: RFID teknolojisi kullanım niyeti, cinsiyete göre farklılık göstermektedir.

H6: RFID teknolojisi kullanım niyeti, öğrenim görülen Fakülteye göre farklılık göstermektedir.

H7: RFID teknolojisi kullanım niyeti, öğrenim görülen sınıfa göre farklılık göstermektedir.

Verilerin Analizi ve Değerlendirilmesi: Çalışma için 330 öğrenciden online anket yöntemiyle elde edilen verilerin analizlerinde farklı istatistiksel yöntemlere başvurulmuştur. Araştırmada, frekans, aritmetik ortalama ve standart sapma, açılayıcı faktör analizi, güvenilirlik analizi, çoklu regresyon analizi t-testi ve tek yön Anova analizi yapılmıştır. Analizlerde SPSS 22.0 paket programı kullanılmıştır.

Katılımcıların Demografik Özellikleri: Araştırmada yer alan katılımcıların demografik özelliklerine ait frekans dağılımları ve yüzdelik dilimde gösterimleri Tablo 1'de sunulmuştur.

Tablo 1'den elde edilen bilgilere göre, araştırmaya konu olan katılımcların, cinsiyet olarak \%49,4'ü kadın, \%50,6'sı erkektir. Katılımcıların \%29,1'i İktisadi ve İdari Bilimler Fakültesinde, \%29,4'ü Edebiyat Fakültesinde, \%29,4'ü Mühendislik-Mimarlık Fakültesinde ve \%12,1'i Fen Fakültesinde öğrencidir. Katılımciların \%51,2'si dördüncü sınıf, \%24,8'i birinci sınıf, \%13'ü ikinci sınıf ve \%10,9'u ise üçüncü sınıf öğrencisidir. 
Tablo 1. Katılımcılarn Demografik Özellikleri

\begin{tabular}{llll}
\hline \multicolumn{2}{l}{ Demografik Değişken } & Frekans & Yüzde \\
\hline Cinsiyet & Kadın & 163 & 49,4 \\
& Erkek & 167 & 50,6 \\
& İ̈Bülte & 96 & 29,1 \\
& Edebiyat & 97 & 29,4 \\
& Mühendislik-Mimarlık & 97 & 29,4 \\
\multirow{3}{*}{ Sinıf } & Fen & 40 & 12,1 \\
& 1. Sinıf & 82 & 24,8 \\
& 2. Sinıf & 43 & 13,0 \\
& 3. Sinıf & 36 & 10,9 \\
& 4. Sinıf & 169 & 51,2 \\
\hline
\end{tabular}

Katılımcıların Kişisel Bilgilere Erişim Kontrolü ve Paylaşma İsteği, Yasal Düzenleme, Kültür ve Arkadaş Çevresi Etkisi, Kullanım Kolaylığı ve Kullanışlılık ve RFID Teknolojisi Kullanım Niyetine Yönelik Değerlendirmeleri

Araştırmaya katılan katılımcların, kişisel bilgilere erişim kontrolü ve paylaşma isteğine yönelik değerlendirmelerinin standart sapma ve aritmetik ortalamaları Tablo 2'de sunulmuştur.

Tablo 2. Katılımcıların Kişisel Bilgilere Erişim Kontrolü ve Paylaşma İsteğine Yönelik Değerlendirmeleri

\begin{tabular}{|c|c|c|}
\hline Değişken & $\begin{array}{l}\text { Ortalama De- } \\
\text { ğer }\end{array}$ & $\begin{array}{l}\text { Standart } \\
\text { Sapma }\end{array}$ \\
\hline Kişisel Bilgilere Erişim Kontrolü ve Paylaşma İsteği & 3,054 & 93409 \\
\hline $\begin{array}{l}\text { KBEK1 Öğretmenlerimin, kişisel bilgilerime erişim yetkisini kontrol } \\
\text { etmek benim için önemlidir. }\end{array}$ & 3,58 & 1,411 \\
\hline $\begin{array}{l}\text { KBEK2 Okul Yönetiminin ya da patronumun, kişisel bilgilerime eri- } \\
\text { şim yetkisini kontrol etmek benim için önemlidir. }\end{array}$ & 3,61 & 1,453 \\
\hline $\begin{array}{l}\text { KBEK3 Doktorumun, kişisel bilgilerime erişim yetkisini kontrol et- } \\
\text { mek benim için önemlidir. }\end{array}$ & 3,60 & 1,437 \\
\hline $\begin{array}{l}\text { KBEK4 Resmî kurumların, kişisel bilgilerime erişim yetkisini kontrol } \\
\text { etmek benim için önemlidir. }\end{array}$ & 3,63 & 1,437 \\
\hline $\begin{array}{l}\text { KBEK5 Ürün ya da hizmet aldığım kurumların ya da şirketlerin, kişi- } \\
\text { sel bilgilerime erişim yetkisini kontrol etmek benim için önemlidir. }\end{array}$ & 3,57 & 1,529 \\
\hline KBPİ1 Öğretmenlerimle, kişisel bilgilerimi paylaşmak isterim & 2,51 & 1,125 \\
\hline $\begin{array}{l}\text { KBPİ2 Okul Yönetimi ya da patronumla, kişisel bilgilerimi paylaş- } \\
\text { mak isterim }\end{array}$ & 2,38 & 1,074 \\
\hline KBPİ3 Doktorumla, kişisel bilgilerimi paylaşmak isterim & 2,85 & 1,244 \\
\hline KBPİ4 Resmî Kurumlarla, kişisel bilgilerimi paylaşmak isterim & 2,60 & 1,189 \\
\hline $\begin{array}{l}\text { KBPİ5 Ürün ya da Hizmet Aldığım Kurumlar ya da Şirketlerle, kişi- } \\
\text { sel bilgilerimi paylaşmak isterim }\end{array}$ & 2,21 & 1,120 \\
\hline
\end{tabular}


Tabloda 2'ye göre, kişisel bilgilere erişim kontrolü ve paylaşma isteği değişkeninde yer alan ifadelere verilen cevapların genel ortalaması 3,054'tür. Katılımcların, cevaplarına göre; en yüksek değere sahip olana ifade 3,63 ortalamayla "Resmî kurumların, kişisel bilgilerime erişim yetkisini kontrol etmek benim için önemlidir." ifadesi olup, bu ifadeyi 3,61 ortalamayla "Okul yönetiminin ya da patronumun, kişisel bilgilerime erişim yetkisini kontrol etmek benim için önemlidir." ifadesi takip etmektedir. Elde edilen ortalamalar doğrultusunda, katılımcılar için kişisel bilgilerine yönelik erişimi kontrol edebilmek önemlidir.

Katılımcıların yasal düzenlemeye yönelik değerlendirmelerinin standart sapma ve aritmetik ortalamaları Tablo 3'te sunulmuştur.

Tablo 3. Katılımcılarnn Yasal Düzenlemeye Yönelik Değerlendirmeleri

\begin{tabular}{|c|c|c|}
\hline Değişken & $\begin{array}{l}\text { Ortalama De- } \\
\text { ğer }\end{array}$ & $\begin{array}{l}\text { Standart } \\
\text { Sapma }\end{array}$ \\
\hline Yasal Düzenleme & 3,876 & 1,11366 \\
\hline $\begin{array}{l}\text { YD1 Bireyler, kişisel bilgilerinin toplanılması, kullanılması ve yayıl- } \\
\text { masını kontrol edebilecek haklara sahip olmalıdırlar. }\end{array}$ & 3,98 & 1,364 \\
\hline $\begin{array}{l}\text { YD2 Kişisel bilgilerimin güvenli bir şekilde elde edilip depolanaca- } \\
\text { ğını bilirsem, RFID teknolojisini kullanacağım. }\end{array}$ & 3,58 & 1,253 \\
\hline $\begin{array}{l}\text { YD3 RFID teknolojisi kullanımından dolayı kişisel bilgilere yönelik } \\
\text { gelebilecek muhtemel saldırıları engellemek için, Türkiye Cumhu- } \\
\text { riyeti'nin bir birim kurması gerektiğini düşünüyorum. }\end{array}$ & 3,95 & 1,246 \\
\hline $\begin{array}{l}\text { YD4 RFID teknolojisi kullanımıyla, hangi bilgilerin elde edileceğini } \\
\text { bilme hakkını veren kanunları desteklerim }\end{array}$ & 3,90 & 1,221 \\
\hline $\begin{array}{l}\text { YD5 RFID teknolojisi kullanırken hassas bilgilere erişim boyutunun } \\
\text { düzenlenmesi gerektiğine inanıyorum. }\end{array}$ & 3,97 & 1,229 \\
\hline
\end{tabular}

Tabloda 3'e göre, katılımcıların, yasal düzenleme değişkeninde yer alan ifadelere verdikleri cevapların genel ortalaması 3,876'dır. Katılımcların, cevaplarına göre; en yüksek değer 3,98 ortalamayla "Bireyler, kişisel bilgilerinin toplanılması, kullanılması ve yayılmasını kontrol edebilecek haklara sahip olmalıdırlar." ifadesi olup, bu ifadeyi 3,97 ortalamayla "RFID teknolojisi kullanırken hassas bilgilere erişim boyutunun düzenlenmesi gerektiğine inanıyorum." ifadesi takip etmektedir. Elde edilen ortalamalar doğrultusunda, katılımcların kişisel bilgilere erişimin kontrolü için sağlanacak haklara ve kişisel bilgilere erişim boyutunun kontrolünü sağlayacak düzenlemelere önem verdikleri görülmektedir. 
Katılımcların Kültür ve Arkadaş Çevresi Etkisine Yönelik Değerlendirmeleri değerlendirmelerinin standart sapma ve aritmetik ortalamaları Tablo 4'te sunulmuştur.

Tablo 4. Katılımcılarn Kültür ve Arkadaş Çevresi Etkisine Yönelik Değerlendirmeleri

\begin{tabular}{lll}
\hline Değişken & $\begin{array}{l}\text { Ortalama De- } \\
\text { ğer }\end{array}$ & $\begin{array}{l}\text { Standart } \\
\text { Sapma }\end{array}$ \\
\hline $\begin{array}{l}\text { Kültür ve Arkadaş Çevresi Etkisi } \\
\begin{array}{l}\text { KACE1 Sosyal norm ve inanışlarımla örtüşmeyen teknolojileri kul- } \\
\text { lanmam. }\end{array}\end{array}$ & 3,16 & 3,23 \\
$\begin{array}{l}\text { KACE2 Arkadaşlarımın fikirlerini dikkate almadan RFID teknoloji- } \\
\text { sini kullanacağım. }\end{array}$ & 2,68 & 1,352 \\
$\begin{array}{l}\text { KACE3 Arkadaş gruplarına katılmama yardımci olursa, RFID tek- } \\
\text { nolojisini kullanacağım. }\end{array}$ & 2,89 & 1,102 \\
$\begin{array}{l}\text { KACE4 RFID teknolojisine yönelik daha fazla bilgiye sahip olur- } \\
\text { sam, RFID teknolojisi kullanımıla ilgili daha iyi kararlar verebili- } \\
\text { rim. }\end{array}$ & 3,84 & 1,197 \\
$\begin{array}{l}\text { KACE5 Başkaları tarafindan kullanılan teknolojiyi kullanırken, } \\
\text { kendimi daha rahat hissederim. }\end{array}$ & 3,16 & 1,247 \\
\hline
\end{tabular}

Tablo 4'e göre, katılımcıların, kültür ve arkadaş çevresi etkisi değişkeninde yer alan ifadelere verdikleri cevapların genel ortalaması 3,16'dır. Katılımcıların, cevaplarına göre; en yüksek değer 3,84 ortalamayla "RFID teknolojisine yönelik daha fazla bilgiye sahip olursam, RFID teknolojisi kullanımıla ilgili daha iyi kararlar verebilirim." ifadesi olup, bu ifadeyi 3,23 ortalamayla "Sosyal norm ve inanışlarımla örtüşmeyen teknolojileri kullanmam." ifadesi takip etmektedir. Elde edilen ortalamalar doğrultusunda, katılımcılar için yeni teknolojileri kullanımına başlamak için kullanılacak teknolojiye yönelik daha fazla bilginin elde edilmesi katılımciların sosyal norm ve inanışlarına uygun teknolojiler olmasının gerektiği görülmektedir.

Katılımcıların kullanım kolaylığı ve kullanışlılığa yönelik değerlendirmelerinin standart sapma ve aritmetik ortalamaları Tablo 5 'te sunulmuştur.

Tablo 5'e göre, katılımcıların, kullanım kolaylığı ve fayda değişkeninde yer alan ifadelere verdikleri cevapların genel ortalaması 3,27'dir. Katılımcıların, cevaplarına göre; en yüksek değer 3,39 ortalamayla "Ücretli Yollarda Geçiş yaparken, RFID teknolojisini kullanacağım." ifadesi olup, bu ifadeyi 3,31 ortalamayla "Fatura Öderken, RFID teknolojisini kullanacağım." ifadesi takip etmektedir. 
Katılımcıların RFID Teknolojisi Kullanım Niyetine Yönelik Değerlendirmeleri değerlendirmelerinin standart sapma ve aritmetik ortalamaları Tablo $6^{\prime}$ da sunulmuştur.

Tablo 5. Katılımcıların Kullanım Kolaylığı ve Kullanışhlığa Yönelik Değerlendirmeleri

\begin{tabular}{|c|c|c|}
\hline Değişken & $\begin{array}{l}\text { Ortalama De- } \\
\text { ğer }\end{array}$ & $\begin{array}{l}\text { Standart } \\
\text { Sapma }\end{array}$ \\
\hline Kullanım Kolaylığı ve Fayda & 3,27 & ,93538 \\
\hline KKF1 Market alssverişi yaparken, RFID teknolojisini kullanacağım. & 3,25 & 1,024 \\
\hline KKF2 Fatura öderken, RFID teknolojisini kullanacağım. & 3,31 & 1,002 \\
\hline $\begin{array}{l}\text { KKF3 Ücretli yollarda geçiş yaparken, RFID teknolojisini kullanaca- } \\
\text { ğım. }\end{array}$ & 3,39 & 1,058 \\
\hline KKF4 Finansal kayıt tutarken, RFID teknolojisini kullanacağım. & 3,22 & 1,048 \\
\hline $\begin{array}{l}\text { KKF5 Sınıfta hocanın sorularını cevaplarken, RFID teknolojisini } \\
\text { kullanacağım. }\end{array}$ & 3,18 & 1,077 \\
\hline
\end{tabular}

Tablo 6. Katılımcıların RFID Teknolojisi Kullanım Niyetine Yönelik Değerlendirmeleri

\begin{tabular}{lll}
\hline Değişken & $\begin{array}{l}\text { Ortalama De- } \\
\text { ger }\end{array}$ & $\begin{array}{l}\text { Standart } \\
\text { Sapma }\end{array}$ \\
\hline RFID Teknolojisi Kullanım Niyeti & 3,47 &, 83688 \\
RTKN1 RFID teknolojisini güvenli olmadığını düşünürsem kullan- & 4,07 & 1,217 \\
mayacağım. & & \\
RTKN2 RFID teknolojisini kullanarak rahat olacağım. & 3,14 &, 863 \\
RTKN3 RFID teknolojisini Kullanmak istiyorum. & 3,20 &, 944 \\
\hline
\end{tabular}

Tablo 6'ya göre, katılımcların, RFID Teknolojisi kullanım niyeti değişkeninde yer alan ifadelere verdikleri cevapların genel ortalaması 3,47'dir. Katılımcların, cevaplarına göre; en yüksek değer 4,07 ortalamayla "RFID teknolojisini güvenli olmadığını düşünürsem kullanmayacağım." ifadesi olup, bu ifadeyi 3,20 ortalamayla "RFID teknolojisini kullanmak istiyorum." ifadesi takip etmektedir. Elde edilen ortalamalar doğrultusunda, katılımclar için teknoloji kullanımında güvenliğin önemli bir etken olduğu görülmektedir.

\section{Değişkenlere Ait Açıklayıcı Faktör Analizi ve Güvenilirlik Analizi}

Verilerin faktör analizi için uygun olup olmadığını tespit etmek amacıyla Bartlett Testi ve Kaiser-Meyer-Olkin (KMO) testleri yapılmıştır. Elde edilen sonuçlar Tablo 7'de sunulmuştur. 
Tablo 7. KMO ve Barlett Testi

\begin{tabular}{|c|c|c|c|c|c|}
\hline$\Xi$ & Değişkenler & KMO & Ki-kare $(\chi 2)$ & $\begin{array}{l}\text { Serbestlik Dere- } \\
\text { cesi (sd) }\end{array}$ & $\begin{array}{l}\text { Anlamlılık } \\
\text { Düzeyi (p) }\end{array}$ \\
\hline पूँ & $\begin{array}{l}\text { Kişisel Bilgilere Erişim } \\
\text { Kontrolü ve Paylaşma İs- } \\
\text { teği }\end{array}$ & 863 & 3196,631 & 45 & , 000 \\
\hline$\stackrel{\infty}{\infty}$ & Yasal Düzenleme & ,884 & 1472,489 & 10 & 000 \\
\hline 㞔 & $\begin{array}{l}\text { Kültür ve Arkadaş Çevresi } \\
\text { Etkisi }\end{array}$ & ,758 & 310,853 & 10 & ,000 \\
\hline 吾 & $\begin{array}{l}\text { Kullanım kolaylığı ve kul- } \\
\text { lanışlılık }\end{array}$ & 874 & 1615,730 & 10 & , 000 \\
\hline 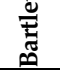 & $\begin{array}{l}\text { RFID Teknolojisi Kullanım } \\
\text { Niyeti }\end{array}$ & 646 & 333,776 & 3 & 000 \\
\hline
\end{tabular}

Tablo 7'ye göre, her değişken için p (Sig) $=0,00<0,05$ olduğundan dolayı Barlett testi sonucu anlamlı olup veriler faktör analizi için uygundur. RFID teknolojisi kullanım niyeti için KMO değeri $(, 646)$ olarak elde edilmiş olup bu değerin 0,60-0,70 arasında bir değer olmasından dolayı, faktör analizine uygunluğu orta seviyededir. Kültür ve arkadaş çevresi etkisi değişkeni için elde edilen KMO değeri (,758) olup bu değerin 0,70-0,80 arasında bir değer olmasından dolayı, faktör analizine uygunluğu iyi seviyededir. Kullanım kolaylığ1 ve kullanışlılık, kişisel bilgilere erişim kontrolü ve paylaşma isteği ve yasal düzenleme değişkenleri için elde edilen KMO değerleri 0,80-0,90 arasında değerler olduğundan dolayı, faktör analizine uygunlukları mükemmel seviyede oldukları görülmektedir.

Analizden çıarılması gereken soruların tespiti için elde edilen Anti-Image Matrislerine ve Ortak varyans (Communlity) tablolarına bakılmıştır. Anti-Image Matrislerinde ve Ortak varyans (Communlity) tablolarında 0,50'den küçük herhangi bir değer olmadığı için herhangi bir soru analizden çıkarılmamıştır.

Değişkenlerin kaç faktörde toplanıldığını saptamak için açıklanan varyans tablosunda yer alan öz değerlere bakılmış ve sadece kişisel bilgilere erişim kontrolü ve paylaşma isteği değişkeninin 1'den büyük iki öz değere sahip olduğu görülmüştür. Dolayısıyla, kişisel bilgilere erişim kontrolü ve paylaşma isteği değişkeninin iki alt boyutta, diğer değişkenlerin ise tek alt boyutta toplandıkları sonucu elde edilmiştir. Kişisel bilgilere erişim kontrolü ve paylaşma isteği değişkeni kişisel bilgilere erişişim kontrolü ve kişisel bilgileri paylaşma isteği olarak adlandırılmıştır. 
Faktörlerin güvenilirliklerinin belirlenmesi amacyyla güvenilirlik analizi yapılarak Cronbach's Alpha değerlerine bakılmıştır. Elde edilen Cronbach's Alpha değerlerine göre elde edilen değerlerin 0,60 üzeri olmasından dolayı oldukça yüksek bir güvenilirliğin oldu görülmektedir.

Tablo 8' de ifadelerin faktör yükleri ve değişkenlerin dağıtıldığı gruplar ile grupların Cronbach's Alpha değerleri sunulmuştur.

Tablo 8. Faktör Gruplar, Faktör Yükleri ve Cronbach's Alpha Değerleri

\begin{tabular}{|c|c|c|c|}
\hline Faktör Adı & İfadeler & Faktör Yükleri & Cronbach's Alpha \\
\hline \multirow{5}{*}{$\begin{array}{l}\text { Kişisel Bilgilere } \\
\text { Erişim Kontrolü }\end{array}$} & KBEK2 & 943 & \multirow{10}{*}{,892 } \\
\hline & KBEK4 & 929 & \\
\hline & KBEK3 & 929 & \\
\hline & KBEK1 & ,925 & \\
\hline & KBEK5 & 897 & \\
\hline \multirow{5}{*}{$\begin{array}{l}\text { Kişisel Bilgileri } \\
\text { Paylaşma İsteği }\end{array}$} & КBPİ2 & 902 & \\
\hline & КВРї1 & 878 & \\
\hline & КВРї4 & 843 & \\
\hline & КВРї3 & ,809 & \\
\hline & KBPİ5 & 790 & \\
\hline \multirow{5}{*}{ Yasal Düzenleme } & YD5 & 939 & \multirow{5}{*}{ 928 } \\
\hline & YD3 & 934 & \\
\hline & YD4 & 921 & \\
\hline & YD1 & 824 & \\
\hline & YD2 & 798 & \\
\hline & KACE4 & 736 & \multirow{5}{*}{ 725 } \\
\hline Kültürr ve Arka- & KACE3 & 735 & \\
\hline daş Çevresi Et- & KACE5 & 735 & \\
\hline \multirow[t]{3}{*}{ kisi } & KACE2 & 657 & \\
\hline & KACE1 & ,596 & \\
\hline & KKF2 & 941 & \multirow{5}{*}{,940 } \\
\hline \multirow{4}{*}{$\begin{array}{l}\text { Kullanım Kolay- } \\
\text { lığı ve Fayda }\end{array}$} & KKF1 & ,929 & \\
\hline & KKF3 & 913 & \\
\hline & KKF4 & 877 & \\
\hline & KKF5 & 831 & \\
\hline \multirow{3}{*}{ Kullanım Niyeti } & RTKN3 & ,893 & \multirow{3}{*}{ 758 } \\
\hline & RTKN2 & 876 & \\
\hline & RTKN1 & ,732 & \\
\hline
\end{tabular}

\section{Değişkenler Arası Etki İçin Çoklu Regresyon Analizi}

RFID teknolojisi kullanım niyetinim tahmin etmek için regresyon modelinin anlamlı olup olmadığını anlamak ve mevcut veriye ne derece iyi uyduğunu görmek için ANOVA testi yapılmış ve elde edilen sonuçlar Tablo 9'da sunulmuştur. 
Tablo 9. Kişisel Bilgilere Erişim Kontrolü ve Paylaşma İsteği, Yasal Düzenleme, Kültür ve Arkadaş Çevresi Etkisi, Kullanım Kolaylığı ve Kullanışhlık ve RFID Teknolojisi Kullanım Niyeti Regresyon Analizi ANOVA Sonuçlarn

\begin{tabular}{lllll}
\hline Bağımlı Değişken & \multicolumn{2}{l}{ Bağımsız Değişkenler } & F & Sig. \\
\hline RFID Teknolojisi Kulla- & 1. & Kişisel Bilgilere Erişim Kontrolü ve & $\mathbf{8 8 , 1 5 5}$ & ,000 \\
nım Niyeti & Paylaşma İsteği & & \\
& 2. & Yasal Düzenleme & \\
& 3. & Kültür ve Arkadaş Çevresi Etkisi & & \\
& 4. & Kullanım Kolaylı̆̆ ve Kullanışlılık & & \\
\hline
\end{tabular}

Tablo 9'da yer alan sonuçlara göre RFID teknolojisi kullanım niyeti bağımlı değişkeni için $f$ değeri $(88,155)$ ve $p$ değeri $=(, 000) 0,001$ 'den küçük olarak elde edilmiştir. Regresyon modelinin anlamlı olduğu görülmektedir. Dolayısıyla, kişisel bilgilere erişim kontrolü ve paylaşma isteği, yasal düzenleme, kültür ve arkadaş çevresi etkisi, kullanım kolaylığı ve kullanışlılık değişkenlerinin ve RFID teknolojisi kullanım niyeti değişkeninin anlamlı tahmin edicileri olduğu görülmektedir.

Bağımlı değişkenler ile bağımsız değişkenler arasında nedensellik ilişkisine bakmak için çoklu regresyon analizi yapılmıştır. Elde edilen sonuçlar Tablo 10' da sunulmuştur.

Tablo 10. RFID teknolojisi kullanım niyeti için Çoklu Regresyon Analizi-1

\begin{tabular}{|c|c|c|c|c|c|}
\hline Değişkenler & $\begin{array}{l}\text { Std. Olm. } \\
\text { Beta }\end{array}$ & Std. Beta & $t$ & P Değeri & VIF \\
\hline \multicolumn{6}{|l|}{ Kişisel Bilgilere } \\
\hline $\begin{array}{l}\text { Erişim Kontrolü } \\
\text { ve Paylaşma İs- } \\
\text { teği }\end{array}$ & 191 & 254 & 5,227 & ,000 & 1,785 \\
\hline $\begin{array}{l}\text { Yasal Düzen- } \\
\text { leme }\end{array}$ & ,223 & ,224 & 4,950 & ,000 & 1,757 \\
\hline $\begin{array}{l}\text { Kültür ve Arka- } \\
\text { daş Çevresi Et- } \\
\text { kisi }\end{array}$ & ,296 & ,331 & 4,394 & ,000 & 1,556 \\
\hline $\begin{array}{l}\text { Kullanım Kolay- } \\
\text { lığı ve Kullanışlı- } \\
\text { lık }\end{array}$ & ,089 & ,099 & 6,911 & ,030 & 1,408 \\
\hline \multicolumn{6}{|c|}{ Bağımlı Değişken: RFID Teknolojisi Kullanım Niyeti } \\
\hline $\mathrm{R}$ & ,721 & & & & \\
\hline $\mathrm{R}^{2}$ &, 520 & & & & \\
\hline Düzeltilmiş $\mathrm{R}^{2}$ &, 514 & & & & \\
\hline D.Watson & 1,976 & & & & \\
\hline
\end{tabular}


Tablo 10'da R değeri (,721) olarak görülmektedir. R2 değeri $(, 520)$ olarak elde edilmiştir ve buna göre bağımsız değişkenlerin, bağımlı değişken olan RFID teknolojisi kullanım niyetini \%52 oranında açıklayabilmektedir. Durbin-Watson değeri $(1,976)$ olarak elde edilmiştir ve 2'ye yakın olduğu için hata terimlerinin bağımsızlığı ön koşulu kabul edilebilmektedir.

Standart hale getirilmiş beta değerlerine baktığımızda en büyük beta katsayıs1 (,331)' dir ve bu değer bize modeldeki diğer değişkenlerin etkisi sabit tutulduğunda, kendi başına bağımlı değişkene en güçlü katkıyı sağlayan bağımsız değişkenin kültür ve arkadaş çevresi etkisi olduğunu göstermektedir. Kültür ve arkadaş çevresi etkisinden sonra $(, 254)$ ile kişisel bilgilere erişim kontrolü ve paylaşma isteği gelmektedir. VIF değerlerinin 10 'dan küçük olmasından ötürü modelde çoklu bağlantı doğrusal programının olmadığı sonucuna varılmıştır.

Tablo 10 'da yer alan p değerleri $(0,00)<0,05$ olduğu için kişisel bilgilere erişim kontrolü ve paylaşma isteği, yasal düzenleme, kültür ve arkadaş çevresi etkisi, kullanım kolaylığı ve kullanışlılık değişkenlerinin RFID teknolojisi kullanım niyeti üzerinde etkiye sahip oldukları sonucu elde edilmiştir. RFID teknolojisi kullanım niyeti değişkenini tahmin etmek için kullanılabilecekleri görülmektedir. Dolayısıyla, H1, H2, H2, H3ve H4 hipotezleri kabul edilmiştir.

RFID Teknolojisi kullanım niyetini tahmin etmek için Regresyon modelinin anlamlı olup olmadığını anlamak ve mevcut veriye ne derece iyi uyduğunu görmek için ANOVA testi yapılmış ve elde edilen sonuçlar Tablo 11 'de sunulmuştur.

Tablo 11. Kişisel Bilgilere Erişim Kontrolü ve Kişisel Bilgileri Paylaşma İsteği ve RFID Teknolojisi Kullanım Niyeti Regresyon Analizi ANOVA Sonuçlan

\begin{tabular}{lllll}
\hline Bağımı Değişken & \multicolumn{2}{l}{ Bağımsız Değişkenler } & F & Sig. \\
\hline RFID Teknolojisi Kullanım & 1. & Kişisel Bilgilere Erişim Kontrolü & \multirow{2}{*}{36,811} & \multirow{2}{*}{000} \\
Niyeti & 2. & Kişisel Bilgileri Paylaşma İsteği & & \\
\hline
\end{tabular}

Tablo 11'de yer alan sonuçlara göre RFID teknolojisi kullanım niyeti bağımlı değişkeni için f değeri $(36,811)$ ve p değeri= $=(000) 0,001$ 'den küçük olarak elde edilmiştir. Regresyon modelinin anlamlı olduğu görülmektedir. Dolayısıyla, kişisel bilgilere erişim kontrolü ve kişisel bilgileri paylaşma isteği, değişkenlerinin ve RFID teknolojisi kullanım niyeti değişkeninin anlamlı tahmin edicileri olduğu görülmektedir. 
Bağımlı değişkenler ile bağımsız değişkenler arasında nedensellik ilişkisine bakmak için çoklu regresyon analizi yapılmıştır. Elde edilen sonuçlar Tablo 12' de sunulmuştur.

Tablo 12. RFID Teknolojisi Kullanım Niyeti İçin Çoklu Regresyon Analizi-2

\begin{tabular}{llllll}
\hline Değişkenler & $\begin{array}{l}\text { Std. Olm. } \\
\text { Beta }\end{array}$ & Std. Beta & $\mathbf{t}$ & P Değeri & VIF \\
\hline $\begin{array}{l}\text { Kişisel Bilgilere Erişim Kont- } \\
\text { rolü }\end{array}$ &, 240 &, 389 & 7,506 &, 000 & 1,074 \\
$\begin{array}{l}\text { Kişisel Bilgileri Paylaşma İs- } \\
\text { teği }\end{array}$ &, 091 &, 106 & 2,046 &, 042 & 1,074 \\
\hline Bağımlı Değişken: RFID Teknolojisi Kullanım Niyeti & & & \\
\hline $\mathrm{R}$ &, 429 & & & \\
$\mathrm{R}^{2}$ &, 184 & & & \\
Düzeltilmiş R $\mathrm{R}^{2}$ &, 179 & & & \\
D.Watson & 1,897 & & & \\
\hline
\end{tabular}

Tablo 12'de R değeri (429) olarak görülmektedir. R2 değeri (,184) olarak elde edilmiştir ve buna göre bağımsız değişkenlerin, bağımlı değişken olan RFID teknolojisi kullanım niyetini \%18 oranında açıklayabilmektedir. Durbin-Watson değeri $(1,897)$ olarak elde edilmiştir ve 2'ye yakın olduğu için hata terimlerinin bağımsızlığı ön koşulu kabul edilebilmektedir.

Standart hale getirilmiş beta değerlerine baktığımızda en büyük beta katsayısı (389) olarak elde edilmiştir. Bu değer bize modeldeki diğer değişkenlerin etkisi sabit tutulduğunda, kendi başına bağımlı değişkene en güçlü katkıyı sağlayan bağımsız değişkenin kişisel bilgilere erişim kontrolü olduğunu göstermektedir. VIF değerlerinin 10'dan küçük olmasından ötürü modelde çoklu bağlantı doğrusal programının olmadığı sonucuna varılmıştır.

Tablo 8 'de yer alan p değerleri $0,05^{\prime}$ ten küçük değerler olduğu için kişisel bilgilere erişim kontrolü ve kişisel bilgilere erişim kontrolü değişkenlerinin RFID teknolojisi kullanım niyeti üzerinde etkiye sahip oldukları ve RFID teknolojisi kullanım niyeti değişkenini tahmin etmek için kullanılabilecekleri görülmektedir. Dolayısıyla H4a ve H4b hipotezleri kabul edilmiştir. 


\section{Katılımcların Cinsiyetleri İle RFID Teknolojisi Kullanım Niyeti Değişkenine Yönelik t Testi Sonuçları}

Cinsiyete göre katılımcıların RFID Teknolojisi Kullanım Niyeti Değişkenine ilişkin t-testi sonuçları Tablo 13'te verilmiştir.

Tablo 13. Katılımcıların Cinsiyetleri İle RFID Teknolojisi Kullanım Niyeti Değişkenine Yönelik t Testi Sonuçlar

\begin{tabular}{llllll}
\hline & $\mathbf{N}$ & Ortalama & Std. Sapma & $\mathbf{t}$ & $\mathbf{p}$ \\
\hline Kadın & 163 & 3,4765 &, 82233 &, 145 &, 885 \\
Erkek & 167 & 3,4631 &, 85326 & & \\
\hline
\end{tabular}

Tablo 13'e göre $t=(, 145)$ ve $p=(, 885)^{\prime}$ tir. Elde edilen $p$ değeri $(, 885)>0,05$ olduğu için RFID teknolojisi kullanım niyetinin cinsiyete göre farklılaşmadığ 1 sonucu elde edilmiştir. Dolayısıyla H5 hipotezi kabul edilmemiştir.

Katılımcıların öğrenim gördükleri fakültelere göre RFID teknolojisi kullanım niyeti değişkenine ilişkin farklılık olup olmadığını belirlemek için tek yönlü varyans analizi yapılmış elde edilen sonuçlar tablo 14'te sunulmuştur.

Tablo 14. Katılımcılarn Öğrenim Gördükleri Fakülte ile RFID Teknolojisi Kullanım Niyeti Değişkenine Yönelik Tek Yönlï Varyans Analizi

\begin{tabular}{|c|c|c|c|c|c|c|}
\hline \multicolumn{2}{|c|}{$\begin{array}{l}\text { RFID Teknolojisi } \\
\text { Kullanım Niyeti }\end{array}$} & $\begin{array}{l}\text { Kareler } \\
\text { Toplamı }\end{array}$ & $\begin{array}{l}\text { Serbestlik } \\
\text { Derecesi }\end{array}$ & $\begin{array}{l}\text { Kareler Orta- } \\
\text { lamasi }\end{array}$ & $F$ & $\begin{array}{l}P \text { De- } \\
\text { geri }\end{array}$ \\
\hline \multirow{3}{*}{$\begin{array}{l}\text { 1. İ̈BF } \\
\text { 2. Edebiyat } \\
\text { 3.Müh.-M. } \\
\text { 4. Fen }\end{array}$} & Gruplar arası & 7,539 & 3 & 2,513 & \multirow{3}{*}{3,676} & \multirow{3}{*}{,012 } \\
\hline & Gruplar içi & 222,880 & 326 & ,684 & & \\
\hline & Toplam & 230,419 & 329 & & & \\
\hline
\end{tabular}

Tablo 14'te yer alan tek yönlü varyans analizi sonuçlarına göre, elde edilen p değeri $=(, 012)<0,05$ olduğu görülmektedir. Bu durumda, RFID teknolojisi kullanım niyetinin katılımcların öğrenim gördükleri fakültelere göre farklılık gösterdiği tespit edilmiştir. Böylece $\mathrm{H} 6$ hipotezi kabul edilmiştir.

Varyansların homojen olup olmadığını belirlemek için Levene testi yapılmış ve elde edilen sonuçlar Tablo 15 'te sunulmuştur.

Tablo 15. Varyansların Homojenliği Testi

\begin{tabular}{lllll} 
RFID Teknolojisi Kulla- & Levene İstatistiği & df1 & df2 & P Değeri \\
\cline { 2 - 5 } nım Niyeti & 3,534 & 3 & 326 &, 015 \\
\hline
\end{tabular}


Tablo 15 'te yer alan değişkenlerin varyanslarının homojenliği kontrol edildiğinde, elde edilen $\mathrm{p}$ değeri $=(, 015)<0,05$ olduğundan çoklu karşılaştırmalar için Tamhane's T2 testi uygulanmıştır. Uygulanan test sonuçları tablo $16^{\prime}$ da sunulmaktadır.

Tablo 16. RFID Teknolojisi Kullanım Niyeti ve Öğrenim Gördükleri Fakültelere Göre Tamhane's T2 Testi Sonuçlarn

\begin{tabular}{|c|c|c|c|c|c|}
\hline $\begin{array}{l}\text { Bağımlı De- } \\
\text { ğişken }\end{array}$ & (I) Fakülte & (J) Fakülte & $\begin{array}{l}\text { Ortalama } \\
\text { Farkı (I-J) }\end{array}$ & $\begin{array}{l}\text { Standart } \\
\text { Hata }\end{array}$ & P Değeri \\
\hline \multirow{12}{*}{ 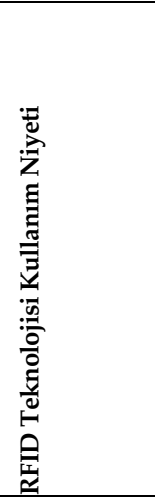 } & \multirow[b]{2}{*}{ Ï̈FF } & Edebiyat & ,25268 & ,12517 & 241 \\
\hline & & $\begin{array}{l}\text { Mühendislik-Mi- } \\
\text { marlık }\end{array}$ &,- 13563 & 11651 & ,816 \\
\hline & \multirow{4}{*}{ Edebiyat } & Fen & ,05208 & 13385 & ,999 \\
\hline & & İ̈BF &,- 25268 & 12517 & 241 \\
\hline & & Müh.-Mim. &,- 38832 & 12352 & ,012 \\
\hline & & Fen &,- 20060 & 14000 & 636 \\
\hline & \multirow{2}{*}{ Müh.- Mim } & İ̈BF & 13563 & 11651 &, 816 \\
\hline & & Edebiyat & ,38832 & 12352 &, 012 \\
\hline & \multirow{4}{*}{ Fen } & Fen & 18771 & 13231 & ,648 \\
\hline & & IївF &,- 05208 & 13385 & ,999 \\
\hline & & Edebiyat & 20060 & 14000 & 636 \\
\hline & & $\begin{array}{l}\text { Mühendislik-Mi- } \\
\text { marlık }\end{array}$ & -,18771 & 13231 & 648 \\
\hline
\end{tabular}

Tablo 16' da yer alan çoklu karşılaştırma tablosuna bakıldığında, $\mathrm{p}$ değeri $(, 012)<0,05$ olduğundan dolayı, Mühendislik ve Mimarlık Fakültesi öğrencileri ile Edebiyat Fakültesi öğrencileri arasında RFID teknolojisi kullanım niyetinin farklılaştığı görülmektedir. Katılımcların sınıflarına göre RFID teknolojisi kullanım niyeti değişkenine ilişkin farklılık olup olmadığını belirlemek için Tek Yönlü Varyans Analizi sonuçları tablo 17' de sunulmuştur.

Tablo 17. Öğrenim Görülen Sınıf ile RFID Teknolojisi Kullanım Niyeti Değişkenine Yönelik Tek Yönlü Varyans Analizi

\begin{tabular}{|c|c|c|c|c|c|c|}
\hline \multicolumn{2}{|c|}{$\begin{array}{l}\text { RFID Teknolojisi Kullanım } \\
\text { Niyeti }\end{array}$} & \multirow{2}{*}{$\begin{array}{l}\text { Kareler } \\
\text { Toplamı }\end{array}$} & \multirow{2}{*}{$\begin{array}{l}\begin{array}{l}\text { Serbestlik } \\
\text { Derecesi }\end{array} \\
3\end{array}$} & \multirow{2}{*}{$\begin{array}{l}\begin{array}{l}\text { Kareler Orta- } \\
\text { lamasi }\end{array} \\
1,566\end{array}$} & \multirow[t]{2}{*}{$\mathbf{F}$} & \multirow[t]{2}{*}{$\begin{array}{l}\text { P De- } \\
\text { geri }\end{array}$} \\
\hline 1.sinuf & Gruplar arası & & & & & \\
\hline 2.sinif & Gruplar içi & 225,721 & 326 & 692 & \multirow{2}{*}{2,262} & \multirow{2}{*}{ 081 } \\
\hline $\begin{array}{l}3 . S i n i f \\
4 . \operatorname{sinf} f\end{array}$ & Toplam & 230,419 & 329 & & & \\
\hline
\end{tabular}

Tablo 17'de yer alan Tek Yönlü Varyans Analizi sonuçlarına göre, elde edilen $p$ değeri $=(, 081)>0,05^{\prime}$ tir. Bu durumda, RFID teknolojisi kullanım niyeti 
katılımcıların sınıflarına göre farklılık göstermemektedir. Böylece H7 hipotezi kabul edilmemiştir.

\section{Sonuç}

Araştırmada, Hossain ve Prybutok (2008) tarafından geliştirilen CARFID Modeli ile öğrencilerin RFID teknolojisi kullanma niyetleri üzerinde kişisel bilgilere erişim kontrolü ve paylaşma isteği, yasal düzenleme, kültür ve arkadaş çevresi etkisi, kullanım kolaylığı ve kullanışlılık değişkenlerinin etkili olup olmadığı araştırılmıştır. Aynı zamanda, RFID teknolojisi kullanma niyetinin cinsiyete, fakültelere ve öğrenim görülen sınıfa göre farklılık gösterip göstermediğine bakılmıştır.

Katılımcıların, kişisel bilgilere erişim kontrolü ve paylaşma isteği, yasal düzenleme, kültür ve arkadaş çevresinin etkisi, kullanım kolaylığı ve kullanışlılık ve RFID teknolojisi kullanım niyetine yönelik değerlendirmeleri için değişkenlerde yer alan aritmetik ortalama ve standart sapmalarına bakılmıştır. Elde edilen ortalamalar doğrultusunda, katılımcılar için RFID teknolojisine yönelik daha fazla bilgiye sahip olma ve bu teknolojinin güvenli bir teknoloji olduğuna dair olumlu algi sahibi olma bu teknolojiyi kullanma arzusu için gerekmektedir. Katılımclların, kişisel bilgilerine erişimi kontrol edebilmeleri ve hangi bilgilere erişimin sağlandığını bilmeleri, kişisel bilgilerin toplanılması ve paylaşılmasını kontrol etmeye yönelik haklara sahip olmaları ve kişisel bilgilere yönelik gelebilecek saldırıları önlemek amacıyla devlet tarafından bir birimin kurularak kişisel verilerin korunması önemlidir. Kişisel verileri korumak amacıyla, Kişisel Verilerin Korunması Kanunu (KVKK) 7 Nisan 2016 tarih ve 29677 sayılı Resmî Gazetede yayımlanarak yürürlüğe girmiştir. Bu kanunla, kişisel verilerin toplanması, erişim yetkisi olmayan bireylerin erişimine açılması, ifşa edilmesi, verilerin amaç dışı veya kötüye kullanımıyla doğabilecek kişilik haklarına yönelik ihlallerin önüne geçilerek engellenmesi amaçlanmaktadır (https://berqnet.com/blog/kvkknedir). Bireylerin, Kişisel Verilerin Korunması Kanunu ile kişisel verilerin korunmasına yönelik bir kanunun olduğunu bilmeleri, RFID teknolojisine yönelik kullanıcı algılarını etkileyebilir.

Anket formunda yer alan faktörlerin geçerliliği için açıklayıcı faktör analizi yapılmış ve analiz sonucu elde edilen sonuçların Hossain ve Prybutok 
(2008:) tarafından yapılan çalışmanın sonuçları ile benzerlik gösterdiği görülmüştür. Güvenilirliğini belirlemek için güvenilirlik analizi yapılarak elde edilen Cronbach's Alpha değerlerine bakılarak, çalışmada kullanılan ölçeklerin genel olarak güvenilir olduğu sonucuna ulaşılmıştır.

Araştırmada, bağımlı değişkenler ile bağımsız değişkenler arasında nedensellik ilişkisine bakmak için çoklu regresyon analizi yapılmıştır. Yapılan çoklu regresyon analizleri ile kişisel bilgilere erişim kontrolü ve paylaşma isteği, yasal düzenleme, kültür ve arkadaş çevresinin etkisi, kullanım kolaylığı ve kullanışlılık değişkenlerinin RFID teknolojisi kullanım niyeti üzerinde etkili olduğu belirlenmiştir. RFID teknolojisine yönelik insanların kullanım kolaylığı ve sağladığı avantajlar ve faydalara yönelik bilgilendirilmesiyle, RFID teknolojisi kullanımı daha da artacaktır. Kültürün ve arkadaş çevresinin teknoloji kabulünde etkin bir role sahip olduğu dikkate alındığında kültürel olarak herhangi bir soruna neden olmayacağına dair bilgilendirmeler ve kişisel verileri korumaya yönelik Kişisel Verilerin Korunması Kanununun yürürlükte olduğunu bilmeleri ile bu teknolojinin kabul edilmesi ve kullanılması artacaktır.

RFID teknolojisi kullanım niyetinin cinsiyete, fakülteye ve öğrenim görülen sınıfa göre farklılaşıp farklılaşmadığını saptamak için t-testi ve tek yön Anova analizleri yapılmıştır. RFID teknolojisi kullanım niyetinin cinsiyete ve öğrenim görülen sınıfa göre farklılaşmadığı, fakat fakülte olarak Mimarlık- Mühendislik Fakültesi ve Edebiyat Fakültesi öğrencileri için RFID teknolojisi kullanım niyetinin farklılık gösterdiği görülmüştür. Bu farklılığın altında yatan neden olarak, mimarlık ve mühendislik bölümü öğrencilerinin, bölümleri gereği daha fazla teknik ve teknoloji ile alakalı dersler almalarının etkisinin olduğu düşünülmektedir.

Bu çalışmada, RFID teknolojisinin öğrenciler tarafından kabulü CARFID modeli ile araştırılmıştır. Benzer konulu çalışma, farklı üniversitelerde, farklı bölümlerde yapılarak bu çalışmayla elde edilen sonuçlarla kıyaslanabilir. Bundan sonraki çalışmalarda, COVID-19 salgını da dikkate alınarak, sosyal mesafe ve temas kurmamada avantaj sağladığı göz önünde bulundurularak, CARFID modeli ile RFID teknolojisi kullanım kabulü, genel kullanıciya yönelik yapılarak elde edilen sonuçlarla literatüre katkıda bulunulabilir. 


\title{
EXTENDED ABSTRACT
}

\section{Review of the User's Acceptance of RFID Technology with the Carfid Model: A Research for University Students}

\author{
Ahmet İlker Akbaba - Muhammet Mutlu \\ Erzurum Technical University
}

RFID technology is considered as the future technology for data storage and asset control. RFID technology is a rapidly developing technology that uses radio waves to store and transfer data without the need for human intervention (Yao, Chu and Li, 2010, p.128). The number of RFID applications has increased thanks to factors such as rapid development, opportunities for systems that make life easier, and affordable costs (Çıbuk and Maraşl1, 2015, p.266). By using RFID technology, many benefits can be obtained. Some of which are: large amounts of data storing ability, detecting objects individually, significant reduction in workloads, increase in company productivity, decrease in stock control and provisioning costs, employing less personnel, having low maintenance costs, working in different and difficult conditions, having the capacity to read labels very fast, being able to be combined with other technologies such as sensors. (Roberts, 2006, p.21, Pala and İnanç, 2007, p.1, Ahuja and Potti 2010, p.183, Kaur, Sandhu, Mohan and Sandhu, 2011, p.154). In addition to the benefits of RFID technology, there are also some disadvantages that should be taken into consideration. Privacy threats to data stored with the use of RFID technology may arise and cause security and privacy problems (Sarma, Weis and Engels, 2002, p.465). Since it is easy to access RFID data, it has become difficult to prevent the cloning of personal information (Ahuja and Potti, 2010, p.185). Sharing data with third parties may cause individuals to be followed by others (Saatçıŏlu, 2006, p.27).

RFID technology, which is thought as similar to barcode technology, is a wireless technology and this technology's systems in provide the opportunity to read and write without touching each other, even in harsh environments where barcode technologies are not used (Bazaat1, 2012, p.7). Although it offers more effective and visible advantages than barcode 
technology, its development has not met expectations (Yao et al., 2010, p.128).

It is aimed in this study to reveal whether the ease of use and usefulness, legal regulations, the effect of culture and friends, the willingness to control access to personal information and share have an effect on the students' intention to use RFID technology and whether the intention to use RFID technology differs according to gender, faculty, and the class of education. For the research, an online questionnaire was applied to 330 students who are enrolled in different faculties at Erzurum Technical University, frequency, arithmetic mean and standard deviation, explanatory factor analysis, reliability analysis, multiple regression analysis t-test, and one-way ANOVA analysis were performed with the SPSS Statistic 22.0 package program.

The arithmetic means and standard deviations of the expressions in the variables were examined for the evaluation of access control and sharing desire to personal information, legal regulation, the effect of culture and friends, ease of use and usefulness, and intention to use RFID technology. It was seen with the obtained arithmetic means that it is necessary for the participants to have more knowledge about RFID technology and to have a positive perception that this technology is a safe technology to use this technology. It is also important for the participants to control access to personal information, to know which information is accessible to others, to have rights about collecting and sharing personal information, and to know there are established units by the government to protect personal information.

Explanatory factor analysis was performed for the validity of the factors in the questionnaire and it was seen that the obtained results were similar to the study the results that is conducted by Hossain and Prybutok (2008). In order to determine its reliability, reliability analysis was performed and it was seen that the scales used in the study were generally reliable.

As a result of multiple regression analysis, it was seen that the variables of access control and willingness of sharing personal information, the legal regulation, the effect of culture and friends, ease of use, and usefulness were effective on the intention to use RFID technology. The use of RFID 
technology can increase even more as people are informed about the ease of use and benefits of RFID technology. By considering that culture and friends have an active role in technology acceptance, the acceptance and use of this technology will increase by informing people that the use of this technology will not cause any problems culturally. Users should informs about that Laws to protect personal data are in force.

T-test and one-way ANOVA analyzes were conducted to determine whether the intention to use RFID technology differs according to gender, faculty, and class of education. It was reached the conclusion that the intention to use RFID technology does not differ according to gender and the class of education, but the intention to use RFID technology differs for the students of the Faculty of Architecture-Engineering and the Faculty of Letters. The reason behind this difference is thought to be due to the fact that the students of architecture and engineering departments take more technical and technology-related courses as required by their departments.

In this study, acceptance of RFID technology by students was investigated with the CARFID model. By conducting similar subjects in different departments in different universities, obtained results can be compared with this study. In future studies, taking into account the COVID-19 epidemic, considering that RFID technology provides advantages in the social distance and non-contacting, the use of RFID technology with the CARFID model can be studied for the general user, and the results obtained can contribute to the literature.

\section{Kaynakça / References}

Ahuja, S. and Potti, P. (2010). An introduction to RFID technology. Commun. Netw., 2(3), 183-186.

Akbaba, A. İ. (2018). Dördüncü endüstri devrimine geçiş sürecinde üç boyutlu yazıcı kullanımının teknoloji kabul modeliyle ölçümlenmesi: Otomotiv endüstrisinde bir araştırma. (Yayımlanmamış doktora tezi). Atatürk Üniversitesi, Sosyal Bilimler Enstitüsü, Erzurum.

Armağan, K., Baysal, M. ve Armağan, C. (2017). Üniversitelerde sosyal medya kabulü. Ĕ̆itim ve Öğretim Araştırmalarn Dergisi, 6(1), 380-386. 
Bayrak, F. (2017). Deniz Araçlarmın kimliklendirilmesi ve takibinde radyo frekanslı tanımlama (RFID) teknolojisinin kullanımı üzerine bir araştırma. Yayınlanmamış Yüksek Lisans Tezi. Dokuz Eylül Üniversitesi, Sosyal Bilimler Enstitüsü, İzmir.

Bazaatı, S. (2012) Inşaat sektöründe Radyo Frekansh Tanıma (RFID) Teknolojisinin malzeme yönetimi üzerindeki etkileri. Yayınlanmamış Yüksek Lisans Tezi. Çukurova Üniversitesi, Fen Bilimler Enstitüsü, Adana.

Bottani, E. and Rizzi, A. (2008). Economical assessment of the impact of RFID Technology and epc system on the fast-moving consumer goods supply chain. International Journal Of Production Economics,112(2008), 548-569.

Chawla, V. and Ha, D. S. (2007). An overview of passive RFID. IEEE Communications Magazine, 45(9), 11-17.

Chen, H. and Papazafeiropoulou, A. (2012). An empirical study for radio frequency identification (RFID) adoption by SMEs in the Taiwanese information technology (IT) industry. Asian Academy of Management Journal, 17(2), 39.

Chen, H., Papazafeiropoulou, A., WU, C.-F. and Huang, T. Y. (2011). Studying RFID Adoption By Smes In The Taiwanese It Industry. European, Mediterranean $\mathcal{E}$ Middle Eastern Conference on Information Systems 2011 (EMCIS2011), (s.1222). Athens.

Cheng, K. M. (2013). An evaluation of RFID door security system at Taipei arena ice land based on technology acceptance model. International Journal of Management $\mathcal{E}$ Information Systems (IJMIS), 17(2), 117-130.

Çelik, H. E., Yılmaz, V. vr Pazarlıoğlu, V. (2010). Teknoloji Kabul Modeli ve Bir Uygulama. Finans Politik E Ekonomik Yorumlar, 47(540), 35-44.

Çıbuk, M. ve Maraşlı, F. (2015). RFID Teknolojisi ve kullanım alanları. BEÜ Fen Bilimleri Dergisi, 4(2), 249-275.

Dinç, M. (2015). Teknoloji bağımlılı̆̆ı ve gençlik. Gençlik Araştırmalan Dergisi, 3(3), 31-65.

Domdouzis, K., Kumar, B. and Anumba, C. (2007). Radio-Frequency Identification (RFID) applications: A brief introduction. Advanced Engineering Informatics, 21(4), 350-355.

Erinç, Ü. (2014). Tedarik zincirinde taşıma birimlerinin RFID ile izlenmesi. Yayınlanmamış Yüksek Lisans Tezi. Bahçeşehir Üniversitesi, Fen Bilimler Enstitüsü, İstanbul.

Hossain, M. M. and Prybutok, V. R. (2008). Consumer acceptance of RFID Technology: An exploratory study. IEEE Transactions on Engineering Management, 55(2), 316-328. 
Jia, X., Feng, Q., Fan, T. and Lei, Q. (2012, April). RFID technology and its applications in Internet of Things (IoT). In 2012 2nd international conference on consumer electronics, communications and networks (CECNet) (p.1282-1285). IEEE.

Jones, P., Clarke-Hill, C., Hillier, D. and Comfort, D. (2005). The benefits, challenges and impacts of Radio Frequency Identification Technology (RFID) for retailers in the UK. Marketing Intelligence \& Planning, 23(4), 395-402.

Kaur, M., Sandhu, M., Mohan, N. and Sandhu, P. S. (2011). RFID technology principles, advantages, limitations \& its applications. International Journal of Computer and Electrical Engineering, 3(1), 151.

KVKK Nedir ve sorumluluklarımız nelerdir? - Bilinmesi gereken tüm detaylarblog. (n.d.). Erişim Tarihi 02 Mart 2021, Erişim Adresi https://berqnet.com/blog/kvkk-nedir.

Lee, H. and Kim, J. (2006). Privacy threats and issues in mobile RFID. In availability, reliability and security, 2006. ARES 2006. The First International Conference on (p.5). IEEE.

Lee, M. S. (2009). An empirical study about RFID acceptance-focus on the employees In Korea. International Journal For Business Economy Finance Management Science, 1(2), 1044-1053.

Li, J., Wang, Y. F., Zhang, Z. M. and Chu, C. H. (2010, June). Investigating acceptance of RFID in Chinese firms: The technology-organization-environment framework. In 2010 IEEE International Conference on RFID-Technology and Applications (p.263-268). IEEE.

Lin, C. Y. and Ho, Y. H. (2009). RFID technology adoption and supply chain performance: An empirical study in china's logistics industry. Supply Chain Management: An International Journal, 14(5), 369-378.

Müller-Seitz, G., Dautzenberg, K., Creusen, U. and Stromereder, C. (2009). Customer Acceptance of RFID Technology: Evidence From The German Electronic Retail Sector. Journal Of Retailing and Consumer Services, 16(1), 31-39.

Nath, B., Reynolds, F. and Want, R. (2006). RFID technology and applications. IEEE Pervasive computing, 5(1), 22-24.

Norman, A. A., Nasir, M. H. N. M., Fauzi, S. S. M. and Azmi, M. (2009). Consumer acceptance of RFID-enabled services in validating halal status. In 2009 9th International Symposium on Communications and Information Technology (p.911-915). IEEE.

Nysveen, H. and Pedersen, P. E. (2016). Consumer adoption of RFID-enabled services. Applying an extended UTAUT model. Information Systems Frontiers, 18(2), 293-314. 
Ozturk, A. B. ve Hancer, M. (2015). The effects of demographics and past experience on RFID technology acceptance in the hospitality industry. International Journal of Hospitality $\mathcal{E}$ Tourism Administration, 16(3), 275-289.

Pala, Z. ve İnanç, N. (2007). Smart parking applications using RFID technology. 1st Annual RFID Eurasia (p.1-3). IEEE.

Pramatari, K. and Theotokis, A. (2009). Consumer acceptance of RFID-enabled services: A model of multiple attitudes, perceived system characteristics and individual traits. European Journal of Information Systems, 18(6), 541-552.

Roberts, C. M. (2006). Radio frequency identification (RFID). Computers E security, 25(1), 18-26.

Roh, J. J., Kunnathur, A and Tarafdar, M. (2009). Classification of RFID adoption: An expected benefits approach. Information E Management, 46(6), 357-363.

Saatçıŏlu, Ö. Y. (2006). RFID teknolojisi: Fırsatlar, engeller ve örnek uygulamalar. Ege Akademik Bakış Dergisi, 6(1), 24-35.

Saparkhojayev, N. and Guvercin, S. (2012). Attendance Control System based on RFID-technology. International Journal of Computer Science Issues (IJCSI), 9(3), 227.

Sarma, S. E., Weis, S. A. and Engels, D. W. (2002). RFID systems and security and privacy implications. In International workshop on cryptographic hardware and embedded systems (p.454-469). Springer, Berlin, Heidelberg.

Wang, Y. M., Wang, Y. S. and Yang, Y. F. (2010). Understanding the determinants of RFID adoption in the manufacturing industry. Technological forecasting and social change, 77(5), 803-815.

Yao, W., Chu, C. H. and Li, Z. (2010). The Use Of RFID İn Healthcare: Benefits and Barriers. In RFID-Technology And Applications (RFID-TA), 2010 IEEE International Conference On (p.128-134). IEEE.

Zhangm, T., Ouyang, Y. and He, Y. (2008). Traceable air baggage handling system based on RFID tags in the airport. Journal of Theoretical and Applied Electronic Commerce Research, 3(1), 106-115.

\section{Kaynakça Bilgisi / Citation Information}

Akbaba, A. İ. ve Mutlu, M. (2021). RFID teknolojisinin kullanıcılar tarafından kabulünün Carfid Modeli ile incelenmesi: Üniversite öğrencilerine yönelik bir araştırma. OPUS-Uluslararası Toplum Araştırmaları Dergisi, 18(41), 3471-3502. DOI: 10.26466/opus.927695. 